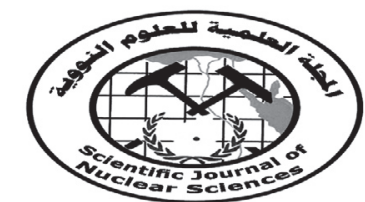

Nuclear Materials Authority

P.O.Box 530 Maadi, Cairo, Egypt
ISSN 2314-5609

Nuclear Sciences Scientific Journal vol. $1, \mathrm{p} 43-56$

2012

\title{
MINERALOGY AND RADIOACTIVITY OF THE ACIDIC DOKHAN VOLCANICS OF GABAL NUQARA, CENTRAL EASTERN DESERT. EGYPT.
}

\author{
SALAH S. ELBALAKSSY, MOHAMED A. ALI and MOHAMED O.ELHUSSEINY \\ Nuclear Materials Authority, P.O. Box 530, El Maadi, Cairo, Egypt
}

\begin{abstract}
The present work aims to study the mineralogy as well as the radioactivity of the acidic Dokhan volcanic in Gabal Nuqara area to identify the minerals that responsible for the radioactivity. The Dokhan volcanic of Gabal Nuqara, Central Eastern Desert are related to fissure-type eruption and are subdivided into intermediate and acidic volcanics. The acidic Dokhan volcanics rocks are located as two elongated flows of rhyolite, dacite and their tuffs, trending NW-SE direction and cut by younger granites and younger gabbros.

Radiomatically, tuffs and dacite rocks show low radioactivity, while the concerned rhyolite exhibits relatively high eTh and eU contents ( $140 \mathrm{ppm}$ and $89 \mathrm{ppm}$ in average respectively). Moreover, an anomalous content was recorded in rhyolite rocks where eTh and eU contents are $745 \mathrm{ppm}$ and $280 \mathrm{ppm}$ in average, respectively.

The detailed mineralogical studies, using ESEM and XRD techniques, indicate the presence of some primary radioactive minerals that are responsible for the radioactivity of the Nuqara rhyolites (e.g. thorite and uranothorite). Furthermore, samarskite, zircon and allanite occur as uraniferous accessory minerals. The mineral chemistry by EPMA analysis of thorite reflects the main following components; $\mathrm{ThO}_{2}(38 \%)$, $\mathrm{SiO}_{2}(33 \%)$ and $\mathrm{UO}_{2}(6 \%)$, while the main constituents of uranothorite are $\mathrm{ThO}_{2}(40 \%), \mathrm{SiO}_{2}(20 \%)$, and $\mathrm{UO}_{2}(12 \%)$. Beside, the studied zircon crystals display a large chemical variability between core and rim. Zircon and thorite from Nuqara rhyolite are demonstrably magmatic origin, can be attributed concentrated in the rhyolite extrusive rocks in the late stage of the volcanoes in the study area.
\end{abstract}

\section{INTRODUCTION}

The present work aims to study the mineralogy as well as the radioactivity of the acidic Dokhan volcanic in Gabal Nuqara area to identify the minerals that responsible for the radioactivity. Gabal Nuqara area is located along the Red Sea coast, about $6 \mathrm{~km}$ west Safaga city. It is bounded by Lat. $26^{\circ} 38^{\prime}$ and $26^{\circ}$ $45^{\prime} \mathrm{N}$ and Long. $33^{\circ} 47^{\prime}$ and $33^{\circ} 56^{\prime} \mathrm{E}$ (Fig.1). Several workers described Dokhan volcanics in different areas, and most of them agreed to their calc-alkaline nature (e.g. Basta et al.1978, 1980). The first records of the Dokhan volcanic were reported by Hume (1934) in the North Eastern Desert, where they were called the Dokhan volcanic. Engel et al. (1980) believe that the Dokhan volcanics represent the surface indication of the first stage of Pan-African-enriched plutonic activity. Heikal et al. (1980) described the rhyolitic ignimbrites in the Wassif area, southwest of Safaga. Dokhan volcanics were recorded in the Central Eastern Desert at Wadi Sodmein area north of Gabal Meatiq and in Wadi Kariem, south of the Qift-Quseir road (Ries et al., 1983). Dokhan volcanics and their plutonic equivalent in Gabal Nuqara area were studied by many authors 
such (e.g. Hamad, (1978); Hilmy et al., (1983); Ragab, (1987); Ali, (1995), and El Mansi, et al., (2003). Hassan and Long (2007) used Rb$\mathrm{Sr}$ isochron age dating for Dokhan volcanics of different localities in the Eastern Desert. They reported an age of $619 \pm 19$ Ma for intermediate Dokhan volcanics while acidic ones give an age of about 570 Ma of Gabal Nuqara (the study rocks).

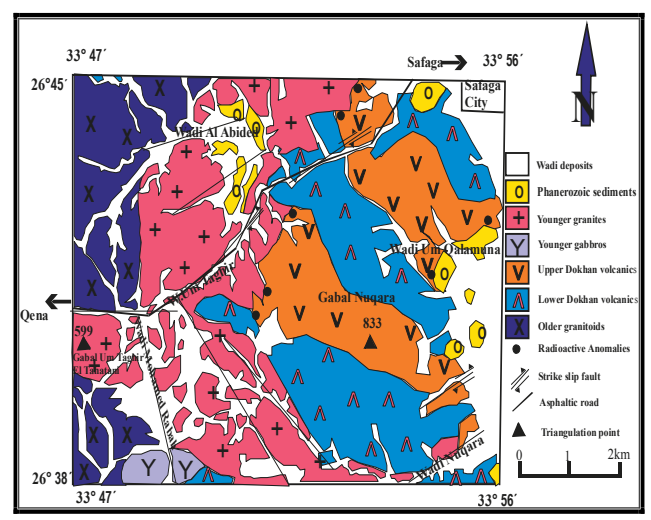

Fig. 1: Sketch geological map of Gabal Nuqara area (Ali, 1995).

Radioactivity of volcanic rocks was previously studied by many authors. In Egypt, Ibrahim et al. (2002) recorded the radioactive pyroclastics of Um Safi area, Eastern Desert, containing secondary U-mineral kasolite and U-bearing minerals columbite and betafite as responsible for the radioactivity. Dawood et al. (2004) studied the radioactivity of El Atshan trachyte, Eastern Desert, and recorded the presence of secondary U-minerals; kasolite, soddyite and uranophane as the responsible of radioactivity of trachyte.

\section{METHODOLOGY}

Geologic map was modified after Ali (1995), as a base map for the whole study area (Fig.1). Firstly, the petrographic characteristics of these rocks were determined. Secondly, quantitative radiometric study was carried out to measure the two radioelement; eU and $\mathrm{eTh}$. Accordingly, the highly radioactive samples of minerals were separated using the heavy liquids, the Frantz Isodynamic Magnetic Sep- arator and purified under the binocular microscope. The radioactive mineral grains were investigated using the Environmental Scanning Electron Microscope (ESEM) model Philips XL 30 under operating conditions of accelerating voltage $30 \mathrm{kv}$ and account time 60-120 seconds with back-scattered detector (BSE). The results data were confirmed by the X-ray diffraction (XRD) technique model Philips PW- 1050/80.

Moreover, the chemical compositions of zircon, thorite and uranothorite were done, using the JEOL JXA-733 super probe, at 15 $\mathrm{kv}$, with a beam current of $50 \mathrm{nA}$ and at 30 second. Standards were: jadeite, kaersutite, quartz, and apatite ( for $\mathrm{Na}, \mathrm{Al}, \mathrm{Si}, \mathrm{P}$, and $\mathrm{Ca}$, respectively), $\mathrm{SrTiO}_{3}$ (for Ti), $\mathrm{CaF}_{2}$ (for $\mathrm{F}$ ), $\mathrm{Fe}$, $\mathrm{Nb}, \mathrm{Hf}, \mathrm{Ta}, \mathrm{Sn}, \mathrm{Th}$, and $\mathrm{U}$ metals (for $\mathrm{Fe}, \mathrm{Nb}$, $\mathrm{Hf}, \mathrm{Ta}, \mathrm{Sn}, \mathrm{Th}$, and $\mathrm{U}$, respectively), YAG (for $\mathrm{Y})$, cubic zirconia (for $\mathrm{Zr}$ ), Ce, Sm, Pr, Er, Gd, $\mathrm{Eu}, \mathrm{Dy}$, and $\mathrm{Yb} \mathrm{Al} \mathrm{Si}$ bearing glass, for $(\mathrm{Ce}$, $\mathrm{Sm}, \mathrm{Pr}, \mathrm{Er}, \mathrm{Gd}, \mathrm{Eu}, \mathrm{Dy}$, and $\mathrm{Yb}$ ) and crocoite for $(\mathrm{Pb})$. All analyses were carried out in the Nuclear Materials Authority Labs. (NMA), while the chemical compositions of some radioactive minerals were achieved in the New Brunswick University (UNB), Canada.

\section{FIELD GEOLOGY}

Dokhan volcanics of Gabal Nuqara represent a conspicuous rock unit, forming a more or less circular outline; cover an area of about $95 \mathrm{~km}^{2}$ (Fig.1). Based on field relation, the Dokhan volcanic in the studied area, could be subdivided into two groups: 1) Lower Dokhan volcanics (intermediate) and 2) Upper Dokhan volcanics (acidic). The lower Dokhan volcanics subunit is characterized by light to dark grey colours, while the upper Dokhan volcanics subunit is of a faint to reddish pink colours. The Lower Dokhan volcanics crop out in the form of three elongated parallel belts of NW-SE direction and conformably overlain by acidic Dokhan volcanics, which appear as two intercalated elongated belts of the same trend. These parallel belts suggest fissure-type eruption rather than neck-type eruption. 
Compared to the upper Dokhan volcanics, these rocks are highly weathered particularly along the eastern border of the map, nearby the Red Sea coast. While these rocks are possessing several vesicles especially near contacts. Some of these vesicles are dominated by amygdales of different shapes and sizes of carbonate, chlorite and quartz forming. Both Dokhan volcanics subunits are intruded by the younger gabbros and younger granites. The acidic Dokhan volcanics, especially near the contact with younger granites, show several elongated quartz bodies and veinlets. Hematitization is recorded by change the rhyolite color into red to brown especially along fractures due to the presence of impregnation of iron oxides.

\section{PETROGRAPHY}

The microscopic examination for the volcanic rocks under consideration revealed that they are mainly rhyolite, dacite and their tuffs.

Rhyolite:It is composed mainly of quartz, potash feldspars and plagioclase with uniform grain size. Allanite, zircon, apatite and opaque are the accessory minerals. Quartz occupies about $35 \%$ of the rock occurring as equant crystals. Potash feldspars are mainly sanidine occurring as euhedral crystals exhibiting their characteristic Carlsbad twining (Fig. 2). Plagioclase occurs as subhedral crystals of albite exhibiting lamellar and percline twining. Allanite occurs as euhedral crystal with yellowish brown color and masked interference colors (Fig. 3). Zircon and pyrite occur as clusters of minute prismatic crystals (Fig. 4).

Dacite:It is characterized by porphyritic texture. It is composed mainly of groundmass of quartz, plagioclase and potash feldspar occur-

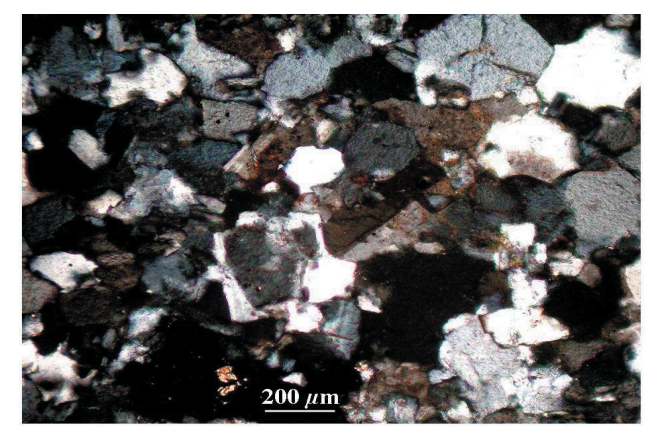

Fig 2: Euhedral crystal of sanidine with simple twining associating quartz and perthite in rhyolite

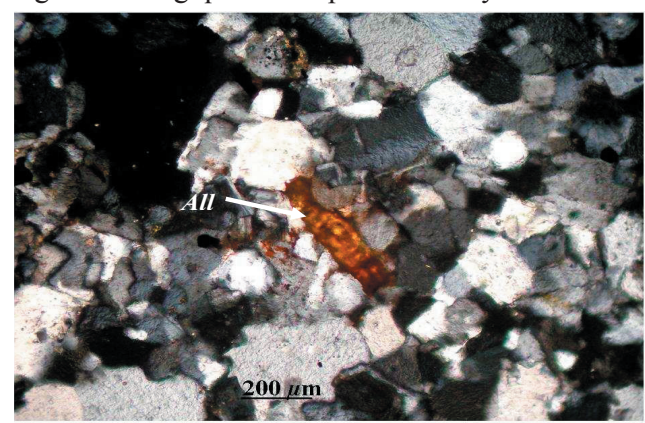

Fig.3: Euhedral crystal of allanite (All) associating quartz and perthite in rhyolite

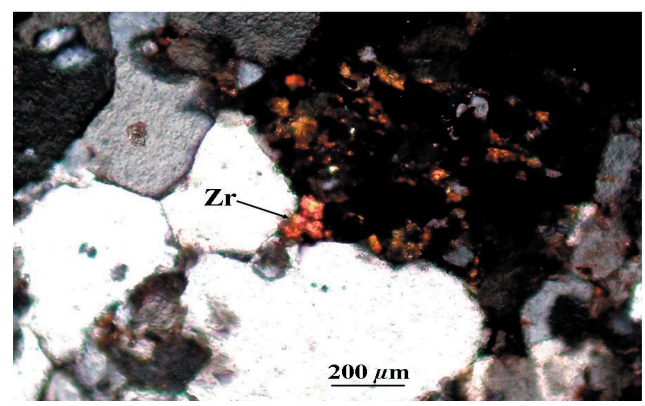

Fig. 4: A cluster of zircon crystals (Zr) and pyrite associating quartz and perthite in rhyolite

ring as crystals and phenocrysts of perthite and plagioclase (Figs. $5 \& 6$ ). Both the groundmass and phenocrysts are stained by iron oxides. Iron oxides also occur as well-formed crystals disseminated in the groundmass and associated with muscovite which is present as minute flakes spreading in the groundmass (Fig. 7). 


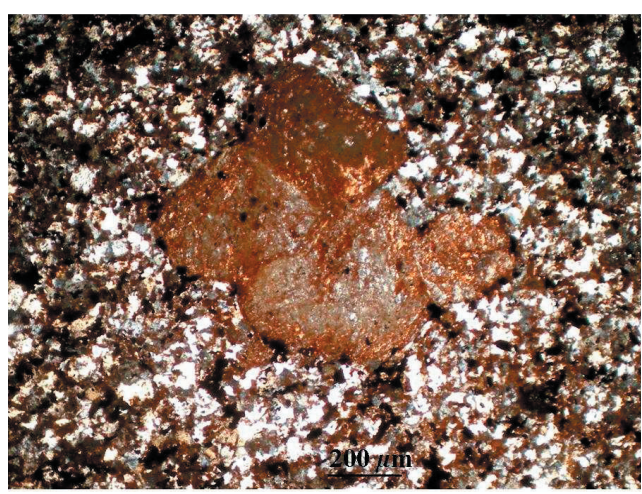

Fig. 5: A phenocryst of perthite stained by iron oxides in groundmass of quartz and feldspars in dacite

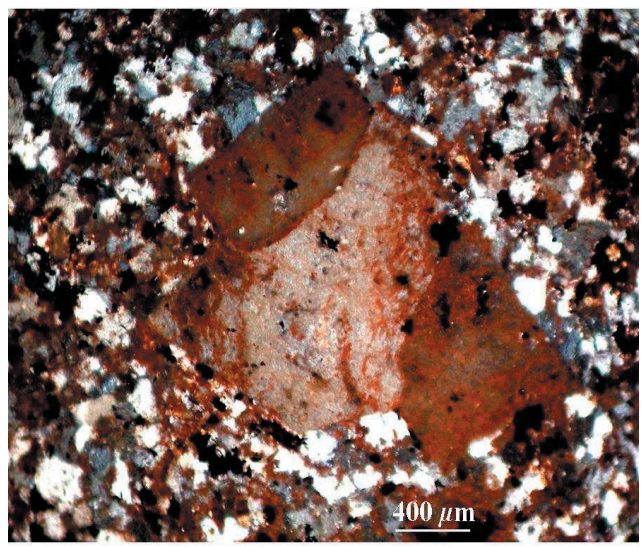

Fig.6: A phenocryst of plagioclase stained by iron oxides in groundmass of quartz and feldspars in dacite

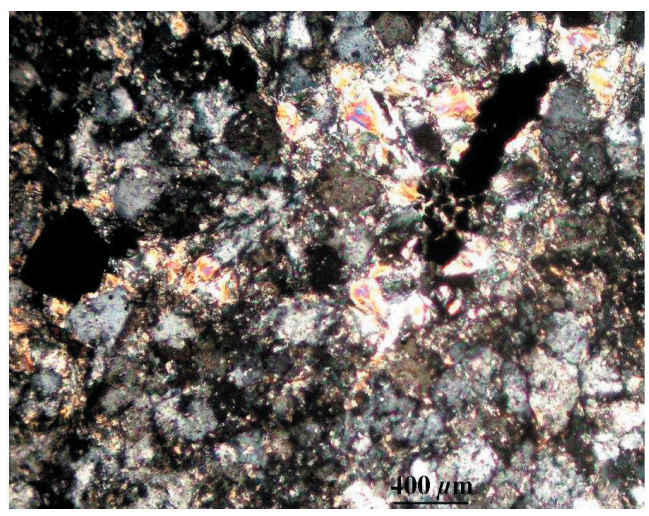

Fig. 7: Minute flakes of muscovite associated with pyrite, quartz and feldspars as groundmass in dacite

\section{RADIOACTIVITY}

Generally, the acidic volcanic rocks exhibits often 1.5 to 2 times higher in uranium content than their intrusive equivalents; granites (Klepper and Wyand, 1956). Table (1) shows that the eU content in the tuffs, ranges from 2 to $6 \mathrm{ppm}$ with an average of $4 \mathrm{ppm}$, and the eTh content ranges from 5 to $15 \mathrm{ppm}$ with an average of $10 \mathrm{ppm}$, while the average of $\mathrm{eTh} /$ $\mathrm{eU}$ ratio is 2.6. Dacitic rocks show eU content values range from 3 to $9 \mathrm{ppm}$ with an average of $6 \mathrm{ppm}$, and eTh ranges from 9 to $17 \mathrm{ppm}$ with an average of $15 \mathrm{ppm}$, while the average of $\mathrm{eTh} / \mathrm{eU}$ ratio is 2.5 . On the other hand, rhyolites record the highest values of both $\mathrm{eU}$ and eTh where the averages are 89 and $140 \mathrm{ppm}$ respectively, while the average of eTh/eU ratio is 1.9. The anomalous rhyolite rocks show enrichment in the eTh and eU (745 ppm and $280 \mathrm{ppm}$ in average respectively).

Table 1: The eU and eTh contents and $\mathrm{eTh} / \mathrm{eU}$ ratio of the studied acidic Dokhan volcanics.

\begin{tabular}{|c|c|c|c|c|c|c|c|c|c|c|}
\hline \multirow{3}{*}{ Rock type } & \multirow{3}{*}{$\begin{array}{l}\text { Meas. } \\
\mathrm{N}_{0} \text {. }\end{array}$} & \multicolumn{3}{|c|}{$\mathrm{eU}$} & \multicolumn{3}{|c|}{ eTh } & \multicolumn{3}{|c|}{ eTh/eU } \\
\hline & & & gess & & $\mathrm{Ra}$ & & & Ran & & \\
\hline & & Min. & Max. & Av. & Min & Max. & Av. & Min. & Max. & Av. \\
\hline Tuffs & 5 & 2 & 6 & 4 & 5 & 15 & 10 & 2.5 & 3 & 2.6 \\
\hline Dacite & 5 & 3 & 9 & 6 & 9 & 17 & 15 & 2.2 & 3.6 & 2.5 \\
\hline Rhyolite & 10 & 7 & 130 & 89 & 19 & 162 & 140 & 1.4 & 2.7 & 1.9 \\
\hline Anomalies in rhyolite & 20 & 10 & 400 & 280 & 50 & 1830 & 745 & 4.0 & 4.8 & 4.5 \\
\hline
\end{tabular}

\section{MINERALOGY}

The Environmental Scanning Electron Microscope (ESEM) and XRD techniques reflect the presence of some minerals that responsible for the radioactivity in the concerned rhyolites such as thorite and uranothorite as primary radioactive minerals. Furthermore, samarskite, zircon, allanite and apatite occurring as uraniferous accessory minerals. A brief description of these minerals is as follows: 
Samarskite: $(\mathrm{Y}, \mathrm{Ce}, \mathrm{U}, \mathrm{Fe})_{3}(\mathrm{Nb}, \mathrm{Ta}, \mathrm{Ti})_{5} \mathbf{O}_{16}$

Samarskite represents group of minerals with chemical formula $\mathrm{A}_{3} \mathrm{~B}_{5} \mathrm{O}_{16}$. The crystal and structure of samarskite are poorly understood because they are chemically complex, usually completely metamict and pervasively altered. The color of samarskite is velvet black to dark brown. The ESEM study and the XRD analysis for the separated grains of samarskite clarified that it is composed mainly of $\mathrm{Nb}_{2} \mathrm{O}_{5}$, $\mathrm{Y}_{2} \mathrm{O}_{3} \mathrm{Ta}_{2} \mathrm{O}_{5}$ and $\mathrm{UO}_{2}$ with appreciable amounts of $\mathrm{Fe}_{2} \mathrm{O}_{3} \mathrm{CaO}$ and $\mathrm{TiO}_{2}$ (Fig. 8). The XRD data of samarskite was shown in Table (2).

Table 2: XRD data of samarskite.

\begin{tabular}{|c|c|c|c|}
\hline \multicolumn{2}{|c|}{ Sample } & \multicolumn{2}{c|}{$\begin{array}{c}\text { Samarskite } \\
(10-398)\end{array}$} \\
\hline $\boldsymbol{d A}^{\boldsymbol{o}}$ & $\boldsymbol{I}_{\boldsymbol{o}}$ & $\boldsymbol{d A}^{\boldsymbol{o}}$ & $\boldsymbol{I / I}_{\boldsymbol{o}}$ \\
\hline 4.04 & 3 & 4.03 & 20 \\
\hline 3.23 & 6 & 3.23 & 30 \\
\hline 3.12 & 14 & 3.13 & 40 \\
\hline 2.99 & 100 & 2.98 & 100 \\
\hline 2.93 & 17 & 2.92 & 90 \\
\hline 2.82 & 4 & 2.81 & 6 \\
\hline 2.77 & 6 & 2.75 & 10 \\
\hline 2.66 & 5 & 2.64 & 6 \\
\hline 2.59 & 9 & 2.59 & 6 \\
\hline 2.53 & 8 & 2.52 & 20 \\
\hline 2.46 & 4 & 2.45 & 10 \\
\hline 1.91 & 5 & 1.909 & 20 \\
\hline 1.83 & 28 & 1.836 & 20 \\
\hline 1.71 & 4 & 1.709 & 20 \\
\hline 1.64 & 3 & 1.63 & 6 \\
\hline 1.56 & 20 & 1.561 & 30 \\
\hline
\end{tabular}

Allanite: $\mathrm{Ca}(\mathrm{Ce}, \mathrm{La}, \mathrm{Y})_{2} \mathrm{Fe}_{2} \mathrm{Al}_{2}\left(\mathrm{O} / \mathrm{OH} \mathrm{SiO}_{4} / \mathrm{Si}_{2} \mathrm{O}_{7}\right)$

Allanite is a member of the epidote group with rare earth elements substituting for Ca. It is an accessory mineral in acidic and intermediate igneous rocks. It varies in color from light brown to black. Because of their similarity to the rare earth elements in ionic radius, $U$ and Th may be incorporated in the structure of allanite. The metamictization of allanite produces an amorphous alteration product due to the destruction of the crystalline structure of allanite by the radioactive decay of its uranium and thorium. EDX data show that allanite is composed essentially of LREE, $\mathrm{Fe}, \mathrm{Ca}$ and $\mathrm{Si}$ as well as some $\mathrm{U}$ and Th content (Fig. 9).
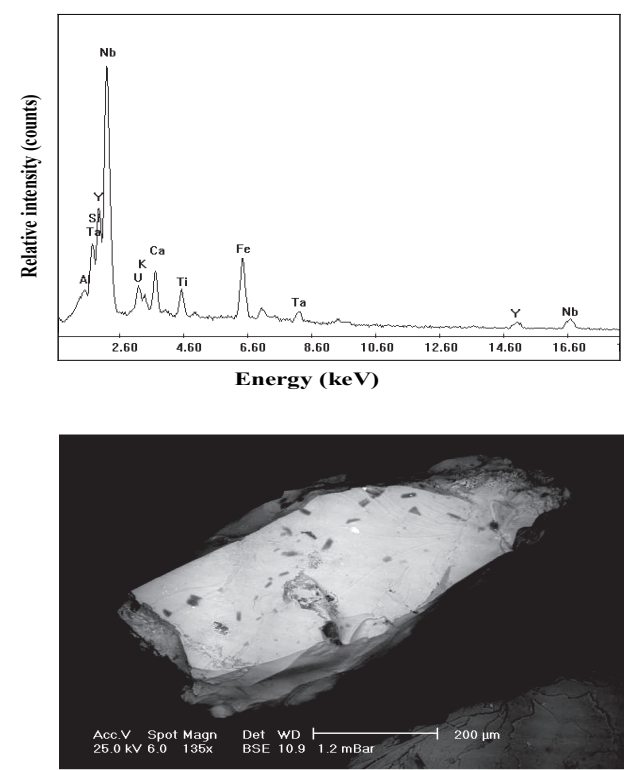

Fig. 8 EDX and BSE image showing samarskite
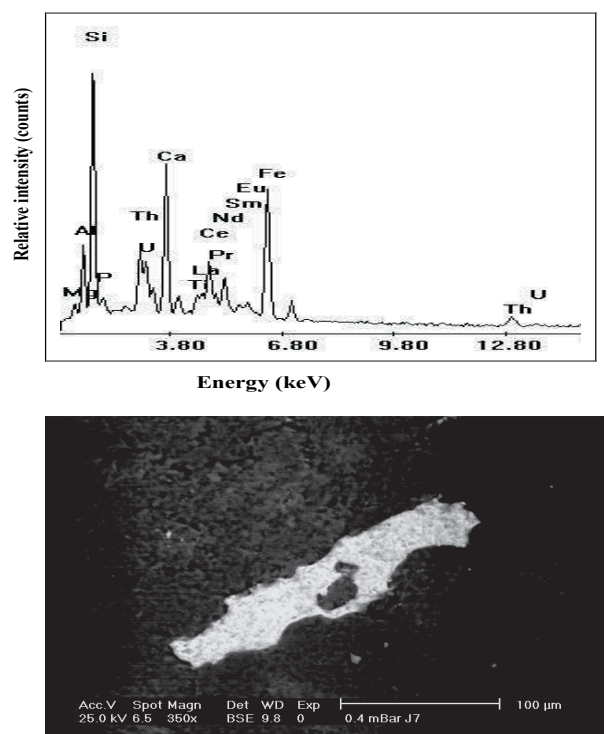

Fig. 9 EDX and BSE image showing allanite 
Pyrite: $\left(\mathrm{FeS}_{2}\right)$

Pyrite occurs as cubic crystals of golden yellow color and metallic luster. EDX analysis shows that the main composition of pyrite is $\mathrm{Fe}$ and S (Fig. 10). The occurrence of pyrite indicates reducing conditions favorable for precipitation of radioactive mineralization. ESEM studies show that pyrite grains contain some bright inclusions of uranothorite.
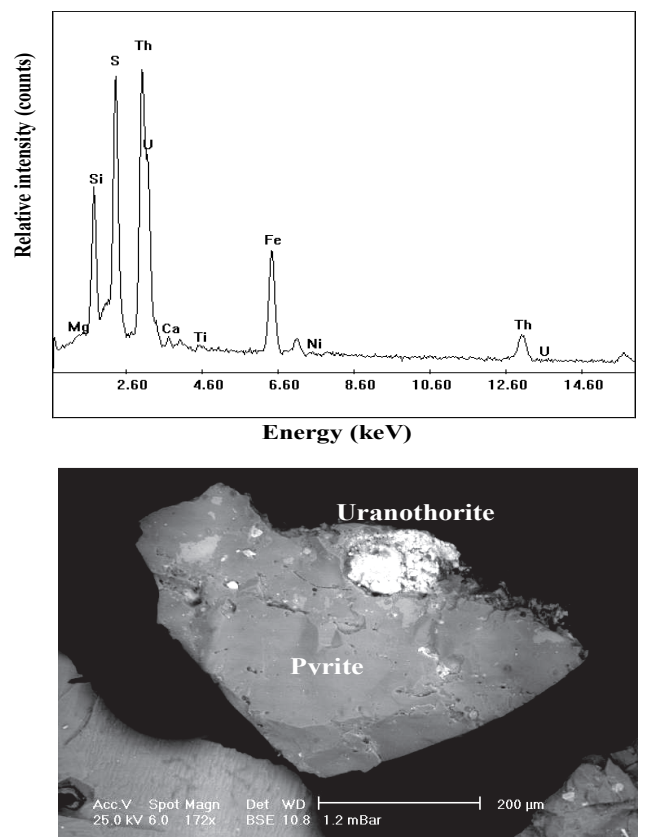

Fig. 10: EDX and BSE image showing uranothorite inclusion in pyrite

Mineral Chemistry of Thorite and Zircon from Nuqara Rhyolite Rocks.

The chemical composition of thorite and zircon from Nuqara rhyolite rocks were achieved using Electron Microprobe techniques (EPMA) that shown in Tables (4\&5).

\section{Thorite: ( $\mathrm{Th} \mathrm{SiO}_{4}$ )}

Thorite is a common radioactive mineral of brown to black color. It occurs as admixture with zircon. Thorite is isomorphic with zircon and it is evident that a large part of thorium is incorporated in the zircon structure by Rankama and Sahama, (1955). EDX analysis shows that thorite is composed of $\mathrm{ThO}_{2}, \mathrm{SiO}_{2}$ in addition to $\mathrm{ZrO}_{2}$ and $\mathrm{Fe}_{2} \mathrm{O}_{3}$ (Fig. 11). It is confirmed by the XRD (Table 3)
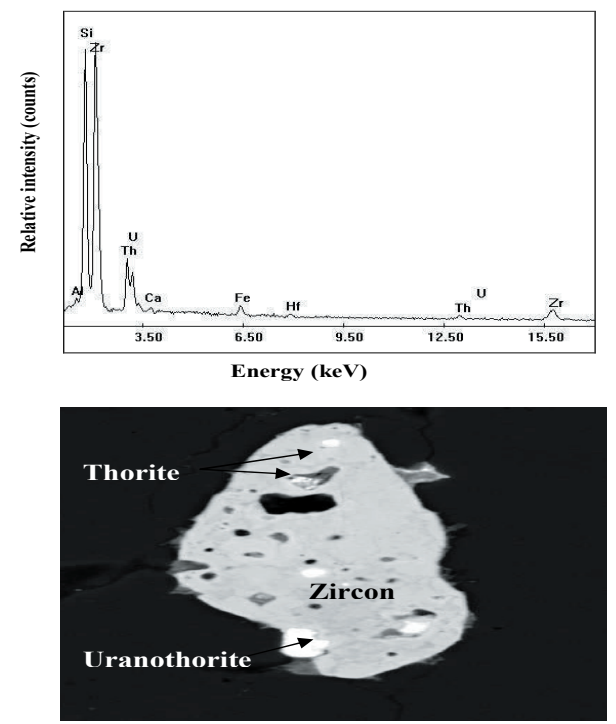

Fig. 11) EDX and BSE image showing thorite and uranothorite inclusions in zircon

Table (3): XRD data of thorite.

\begin{tabular}{|c|c|c|c|}
\hline \multicolumn{2}{|c|}{ Sample } & \multicolumn{2}{c|}{$\begin{array}{c}\text { Thorite } \\
(11-419)\end{array}$} \\
\hline $\boldsymbol{d A}^{\boldsymbol{o}}$ & $\boldsymbol{I}_{\boldsymbol{o}}$ & $\boldsymbol{d \boldsymbol { A } ^ { \boldsymbol { o } }}$ & $\boldsymbol{I} \boldsymbol{I}_{\boldsymbol{o}}$ \\
\hline 4.72 & 11 & 4.72 & 85 \\
\hline 3.56 & 19 & 3.55 & 100 \\
\hline 2.67 & 7 & 2.676 & 75 \\
\hline 2.36 & 5 & 2.361 & 5 \\
\hline 2.22 & 5 & 2.222 & 30 \\
\hline 2.00 & 3 & 2.019 & 20 \\
\hline 1.89 & 6 & 1.885 & 30 \\
\hline 1.83 & 10 & 1.834 & 65 \\
\hline
\end{tabular}

\section{Uranothorite: [Th, $\left.\mathrm{U}\left(\mathrm{SiO}_{4}\right)\right]$}

Uranothorite occurs as numerous subhedral to anhedral bright inclusions in pyrite. It has its main composition $\mathrm{ThO}_{2}, \mathrm{UO}_{2}$ and $\mathrm{SiO}_{2}$ as shown in the EDX analysis (Fig. 10). 
Thorite and uranothorite

The EPMA analyses revealed that the main components of thorite mineral are $\mathrm{ThO}_{2}(38$ $\%), \mathrm{SiO}_{2}(33 \%)$ and $\mathrm{UO}_{2}(6 \%)$ in addition to $\mathrm{ZrO}_{2}(2.77 \%), \mathrm{HfO}_{2}(0.49 \%), \mathrm{FeO}(2.64$ $\%), \mathrm{P}_{2} \mathrm{O}_{5}(3.14 \%), \mathrm{Al}_{2} \mathrm{O}_{3}(3.55 \%), \mathrm{CaO}(1.45$ $\%), \mathrm{Y}_{2} \mathrm{O}_{3}(3.11 \%), \mathrm{Nb}_{2} \mathrm{O}_{5}(0.17 \%), \mathrm{Ta}_{2} \mathrm{O}_{5}$ $(0.22 \%), \mathrm{PbO}(0.14 \%), \mathrm{Ce}_{2} \mathrm{O}_{3}(0.11 \%)$ and
$\mathrm{Yb}_{2} \mathrm{O}_{3}(0.23 \%)$. On the other hand the major components in uranothorite are $\mathrm{ThO}_{2}(40 \%)$, $\mathrm{SiO}_{2}(20 \%)$, and $\mathrm{UO}_{2}(12 \%)$ together with $\mathrm{Y}_{2} \mathrm{O}_{3}(5.18 \%), \mathrm{P}_{2} \mathrm{O}_{5}(4.73 \%), \mathrm{ZrO}_{2}(3.92 \%)$, $\mathrm{FeO}(3.37 \%), \mathrm{AlO}(2.93 \%), \mathrm{CaO}(2.47 \%)$, $\mathrm{TiO}_{2}(0.05 \%), \mathrm{Nb}_{2} \mathrm{O}_{5}(0.05 \%), \mathrm{Ce}_{2} \mathrm{O}_{3}(0.023$ $\%), \mathrm{Yb}_{2} \mathrm{O}_{3}(0.58 \%), \mathrm{HfO}(0.8 \%), \mathrm{Ta}_{2} \mathrm{O}_{5}(0.44$ $\%)$ and $\mathrm{PbO}(0.06 \%)$, which were reported as substitutes in uranothorite (Table 4).

Table 4: Microprobe analysis of thorite and uranothorite in the rhyolite rocks at Nuqara area.

\begin{tabular}{|c|c|c|c|c|}
\hline \multirow[b]{2}{*}{ Oxides } & 1 & 2 & 3 & 4 \\
\hline & Thorite & Thorite & Uranothorite & Uranothorite \\
\hline $\mathbf{A l}_{2} \mathbf{O}_{3}$ & 3.89 & 3.21 & 3.12 & 2.74 \\
\hline $\mathrm{SiO}_{2}$ & 33.13 & 32.83 & 19.87 & 20.24 \\
\hline $\mathbf{P}_{2} \mathbf{O}_{5}$ & 3.01 & 3.26 & 4.3 & 5.15 \\
\hline $\mathrm{CaO}$ & 1.39 & 1.51 & 2.25 & 2.69 \\
\hline $\mathbf{T i O}_{2}$ & 0.062 & 0.067 & 0.041 & 0.049 \\
\hline FeO & 2.532 & 2.738 & 3.06 & 3.68 \\
\hline $\mathbf{Y}_{2} \mathbf{O}_{3}$ & 2.988 & 3.23 & 4.71 & 5.65 \\
\hline $\mathbf{N b}_{2} \mathbf{O}_{5}$ & 0.162 & 0.175 & 0.043 & 0.052 \\
\hline $\mathrm{ZrO}_{2}$ & 3.14 & 2.40 & 4.02 & 3.82 \\
\hline $\mathrm{Ce}_{2} \mathrm{O}_{3}$ & 0.101 & 0.109 & 0.021 & 0.025 \\
\hline $\mathbf{Y} \mathbf{b}_{2} \mathbf{O}_{3}$ & 0.221 & 0.239 & 0.526 & 0.631 \\
\hline $\mathrm{HfO}_{2}$ & 0.466 & 0.503 & 0.724 & 0.869 \\
\hline $\mathbf{T} \mathbf{a}_{2} \mathbf{O}_{5}$ & 0.209 & 0.225 & 0.397 & 0.476 \\
\hline PbO & 0.136 & 0.147 & 0.053 & 0.064 \\
\hline $\mathrm{ThO}_{2}$ & 34.97 & 40.81 & 39.10 & 40.92 \\
\hline $\mathbf{U} \mathbf{O}_{2}$ & 6.06 & 5.56 & 13.12 & 10.96 \\
\hline Total & 92.48 & 97.01 & 95.43 & 98.03 \\
\hline
\end{tabular}

Structural formula on basis of 4 oxygen atom (cpfu)

\begin{tabular}{|c|c|c|c|c|}
\hline $\mathbf{A l}$ & 0.081 & 0.088 & 0.065 & 0.078 \\
\hline $\mathbf{S i}$ & 1.023 & 1.106 & 0.613 & 0.625 \\
\hline $\mathbf{P}$ & 0.078 & 0.082 & 0.108 & 0.129 \\
\hline $\mathbf{C a}$ & 0.039 & 0.042 & 0.062 & 0.075 \\
\hline $\mathbf{T i}$ & 0.002 & 0.002 & 0.001 & 0.002 \\
\hline $\mathbf{F e}$ & 0.079 & 0.086 & 0.096 & 0.115 \\
\hline $\mathbf{Y}$ & 0.062 & 0.067 & 0.098 & 0.118 \\
\hline $\mathbf{Z r}$ & 0.003 & 0.003 & 0.001 & 0.001 \\
\hline $\mathbf{C e}$ & 0.047 & 0.051 & 0.061 & 0.072 \\
\hline $\mathbf{Y b}$ & 0.000 & 0.000 & 0.001 & 0.001 \\
\hline $\mathbf{H f}$ & 0.001 & 0.001 & 0.001 & 0.001 \\
\hline $\mathbf{T a}$ & 0.004 & 0.005 & 0.007 & 0.008 \\
\hline $\mathbf{P b}$ & 0.003 & 0.003 & 0.005 & 0.007 \\
\hline $\mathbf{T h}$ & 0.000 & 0.000 & 0.001 & 0.001 \\
\hline $\mathbf{U}$ & 0.638 & 0.745 & 0.713 & 0.749 \\
\hline
\end{tabular}


Furthermore, the studied thorite is sporadic in $U$ distribution suggesting non-uniform redistributions of $\mathrm{UO}_{2}$ within thorite during magmatic processes. Many papers reported the presence of thorite inclusions in rare metal mineralization and accessory heavy minerals separated from some Egyptian pegmatites (Ali et al., 2005; Abdel Warith et al., 2007). According to Frondel and Cuttito (1955), huttonite and thorite form hydrothermally over a temperature range from $300^{\circ} \mathrm{C}$ to $700^{\circ} \mathrm{C}$. The formation of huttonite is favored by alkaline conditions and thorite by acid conditions.

\section{Zircon: $\left(\mathrm{ZrSiO}_{4}\right)$}

Zircon occurs as euhedral to subhedral prismatic crystals. The EDX data reflect the chemical composition of zircon is $\mathrm{ZrO}_{2}$ and $\mathrm{SiO}_{2}$ with significant amounts of $\mathrm{Th}, \mathrm{U}, \mathrm{Fe}$, $\mathrm{Al}$, and $\mathrm{Ca}$ (Fig. 11). Zircon occurs as euhedral prismatic grains characterized by pale to deep brown in color and generally sub-translucent to opaque with dull luster. The most common habit is the bipyramidal form with various pyramidal faces. However, some zircon crystals are characterized by extremely short prisms and are more or less equidimensional and exhibiting square cross section.

The chemical analyses of zircon by Microprobe show large chemical variability between core and rim of the crystals (Table 5 ). $\mathrm{ZrO}$ varies from $50.99 \%$ to $60.69 \%$ in the core while in zircon rim it ranges from $53.63 \%$ to $57.37 \%$. In contrast, $\mathrm{UO}_{2}$ increases from core to rim, where $\mathrm{UO}_{2}$ varies from $0.382 \%$ to $0.599 \%$ in the core and ranges from $0.760 \%$ to $1.120 \%$ in the rim. Also, $\mathrm{ThO}_{2}$ increases from core to rim where it ranges from $0.016 \%$ to $0.058 \%$ in the core and varies from $0.054 \%$ to $0.244 \%$ in the rim.

Table 5: Microprobe analysis of zircon. from the rhyolite rocks at Nuqara area.

\begin{tabular}{|c|c|c|c|c|c|c|c|c|}
\hline \multirow[b]{2}{*}{ Oxides } & \multicolumn{2}{|c|}{1} & \multicolumn{2}{|c|}{2} & \multicolumn{2}{|c|}{3} & \multicolumn{2}{|c|}{4} \\
\hline & $\begin{array}{l}\text { Zircon } \\
\text { Core }\end{array}$ & $\begin{array}{c}\text { Zircon } \\
\text { Rim }\end{array}$ & $\begin{array}{l}\text { Zircon } \\
\text { Core }\end{array}$ & $\begin{array}{c}\text { Zircon } \\
\text { Rim }\end{array}$ & $\begin{array}{c}\text { Zircon } \\
\text { Core }\end{array}$ & $\begin{array}{c}\text { Zircon } \\
\text { Rim }\end{array}$ & $\begin{array}{c}\text { Zircon } \\
\text { Core }\end{array}$ & $\begin{array}{c}\text { Zircon } \\
\text { Rim }\end{array}$ \\
\hline $\mathrm{Al}_{2} \mathrm{O}_{3}$ & 0.189 & 0.503 & 0.192 & 0.513 & 0.018 & 0.203 & 0.018 & 0.205 \\
\hline $\mathrm{SiO}_{2}$ & 31.67 & 31.93 & 32.02 & 32.53 & 32.02 & 32.10 & 32.58 & 32.49 \\
\hline $\mathrm{P}_{2} \mathrm{O}_{5}$ & 0.072 & 0.096 & 0.072 & 0.098 & 0.180 & 0.204 & 0.183 & 0.206 \\
\hline $\mathrm{CaO}$ & 0.758 & 1.497 & 0.766 & 1.526 & 1.015 & 1.663 & 1.033 & 1.683 \\
\hline $\mathrm{TiO}_{2}$ & 0.000 & 0.000 & 0.000 & 0.000 & 0.000 & 0.014 & 0.000 & 0.014 \\
\hline $\mathrm{MnO}$ & 0.043 & 0.074 & 0.044 & 0.075 & 0.000 & 0.026 & 0.000 & 0.026 \\
\hline $\mathrm{FeO}$ & 0.206 & 0.560 & 0.208 & 0.571 & 0.521 & 0.631 & 0.531 & 0.639 \\
\hline $\mathrm{Y}_{2} \mathrm{O}_{3}$ & 0.064 & 0.52 & 0.065 & 0.530 & 0.451 & 0.394 & 0.459 & 0.398 \\
\hline $\mathrm{ZrO}_{2}$ & 60.29 & 56.30 & 60.96 & 57.37 & 50.99 & 53.63 & 51.88 & 54.27 \\
\hline $\mathrm{HfO}_{2}$ & 7.56 & 5.15 & 6.61 & 4.24 & 11.81 & 8.53 & 12.02 & 8.63 \\
\hline $\mathrm{Ce}_{2} \mathrm{O}_{3}$ & 0.014 & 0.079 & 0.014 & 0.080 & 0.000 & 0.000 & 0.000 & 0.000 \\
\hline $\mathrm{Tb}_{2} \mathrm{O}_{3}$ & 0.051 & 0.000 & 0.052 & 0.000 & 0.000 & 0.141 & 0.000 & 0.143 \\
\hline $\mathrm{Yb}_{2} \mathrm{O}_{3}$ & 0.149 & 0.096 & 0.151 & 0.097 & 0.145 & 0.066 & 0.148 & 0.067 \\
\hline $\mathrm{Ta}_{2} \mathrm{O}_{5}$ & 0.160 & 0.000 & 0.162 & 0.000 & 0.690 & 0.400 & 0.702 & 0.405 \\
\hline $\mathrm{PbO}$ & 0.025 & 0.000 & 0.025 & 0.000 & 0.043 & 0.000 & 0.044 & 0.000 \\
\hline $\mathrm{ThO}_{2}$ & 0.057 & 0.239 & 0.058 & 0.244 & 0.016 & 0.054 & 0.026 & 0.154 \\
\hline $\mathrm{UO}_{2}$ & 0.593 & 1.099 & 0.599 & 1.120 & 0.382 & 0.760 & 0.389 & 0.769 \\
\hline Total & $\begin{array}{l}101.9 \\
\end{array}$ & \begin{tabular}{|l|l|}
98.14 \\
\end{tabular} & 102 & 99.01 & 98.28 & 98.82 & 100.01 & 100.1 \\
\hline \multicolumn{9}{|c|}{$\begin{array}{l}\text { Structural formula on basis of } 4 \text { oxygen } \\
\text { atom (Cpfu) }\end{array}$} \\
\hline Al & 0.004 & 0.011 & 0.004 & 0.011 & 0.001 & 0.004 & 0.001 & 0.004 \\
\hline $\mathrm{Si}$ & 0.978 & 0.986 & 0.988 & 1.004 & 0.988 & 0.991 & 1.006 & 1.003 \\
\hline $\mathbf{P}$ & 0.002 & 0.002 & 0.002 & 0.002 & 0.005 & 0.005 & 0.005 & 0.005 \\
\hline $\mathrm{Ca}$ & 0.021 & 0.042 & 0.021 & 0.043 & 0.028 & 0.046 & 0.029 & 0.047 \\
\hline $\mathrm{Ti}$ & 0.000 & 0.000 & 0.000 & 0.000 & 0.000 & 0.001 & 0.000 & 0.001 \\
\hline Mn & 0.001 & 0.002 & 0.001 & 0.002 & 0.000 & 0.001 & 0.000 & 0.001 \\
\hline $\mathrm{Fe}$ & 0.020 & 0.006 & 0.007 & 0.017 & 0.016 & 0.020 & 0.017 & 0.020 \\
\hline$Y$ & 0.001 & 0.011 & 0.001 & 0.011 & 0.009 & 0.008 & 0.010 & 0.008 \\
\hline $\mathrm{Zr}$ & 0.942 & 0.880 & 0.953 & 0.896 & 0.797 & 0.838 & 0.811 & 0.848 \\
\hline $\mathrm{Ce}$ & 0.001 & 0.003 & 0.001 & 0.004 & 0.000 & 0.000 & 0.000 & 0.000 \\
\hline Tb & 0.001 & 0.000 & 0.001 & 0.000 & 0.000 & 0.003 & 0.000 & 0.003 \\
\hline $\mathrm{Yb}$ & 0.003 & 0.002 & 0.003 & 0.002 & 0.003 & 0.001 & 0.003 & 0.001 \\
\hline Hf & 0.074 & 0.049 & 0.062 & 0.043 & 0.118 & 0.081 & 0.115 & 0.082 \\
\hline $\mathrm{Ta}$ & 0.001 & 0.000 & 0.001 & 0.000 & 0.004 & 0.006 & 0.004 & 0.006 \\
\hline $\mathrm{Pb}$ & 0.000 & 0.000 & 0.000 & 0.000 & 0.001 & 0.000 & 0.001 & 0.000 \\
\hline Th & 0.001 & 0.004 & 0.001 & 0.002 & 0.003 & 0.001 & 0.001 & 0.003 \\
\hline $\mathbf{U}$ & 0.009 & 0.019 & 0.020 & 0.010 & 0.007 & 0.013 & 0.007 & 0.013 \\
\hline
\end{tabular}




\section{Zircon-thorite association}

The present study revealed that zircon and thorite can exists in partially solid solution state due to the similarity in the ionic radii of $\mathrm{Zr}$ and Th by Förster (2006). The thorite and zircon (core and rim) are plotted on the ternary diagram $\left(\mathrm{SiO}_{2}-\mathrm{ZrO}_{2}-\mathrm{ThO}_{2}\right)$; (Fig.12) that reflected the zircon of Nuqara rhyolite is interpreted as metastable solid solution in the series zircon-thorite $\left(\mathrm{ThSiO}_{4}\right)$. The Hf-concentrating mechanism is assumed due to solid-state action (subsolidus reaction) of exsolved fluids rich in $\mathrm{K}^{+}, \mathrm{Na}^{+}, \mathrm{F}-$ and subsequently $\mathrm{H}^{+}$. Zircon and thorite are demonstrably magmatic origin can be attributed to the role of fluorine-rich fluids. Also, fluoride complexes such as [Na (REE) $\left.\mathrm{F}_{4}\right]$ and $\left[(\mathrm{ZrF})\left(\mathrm{REE} \mathrm{F}_{4}\right)_{3}\right]$ in determining the distribution of REE and other trace elements such as $\mathrm{Zr}$ during magmatic processes. Thus, although $\mathrm{Zr}$ and $\mathrm{Th}$ are generally considered as highly immobile element, yet the occurrence of zircon indicates that significant concentrations of $\mathrm{Zr}$ and $\mathrm{Th}$ can be transported under specified F-rich fluids.

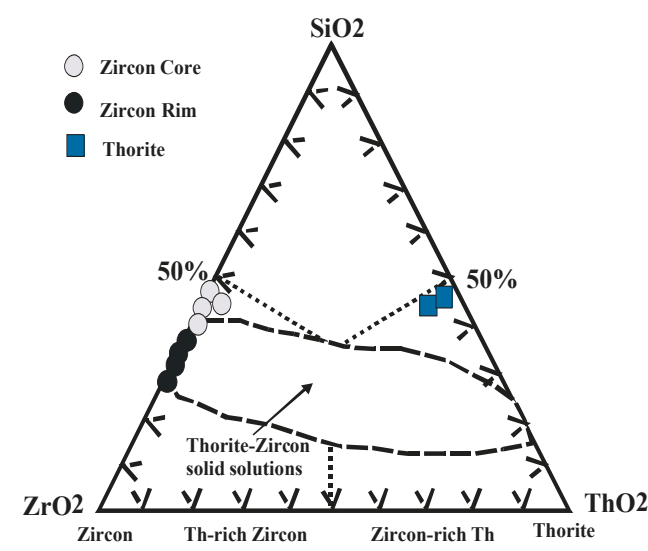

Fig. 12 Composition of thorite and zircon plotted on the basis of $\mathrm{SiO}_{2}-\mathrm{ThO}_{2}-\mathrm{ZrO}_{2}$. The shaded field encloses the composition of thorite-zircon solid solution (Förster, 2006).

\section{Petrogenesis of zircon from Nuqara}

\section{rhyolite rocks}

Due to, $\mathrm{ZrO}_{2}$ increases in zircon core while $\mathrm{UO}_{2}$ and $\mathrm{ThO}_{2}$ are enriched in zircon rims revealing the magmatic origin. These results agreed in accordance with (Bibikova, 1979; Pagel, 1982; Bao, 1995 and El Balakssy, 2010). Besides, the studied zircon shows high content of Hf ranging between $4.24 \%$ and $12.02 \%$ (Table 4 ), compared with the rhyolite zircon of Bishop tuff (1.04-1.29 $\%$ ); (Wark and Miller, 1993). Therefore, it refer as hafnian zircon (\#Hf $=5-18)$; according to the scheme of Correia Neves et al. (1974) on the isomorphous zircon $\left(\mathrm{ZrSiO}_{4}\right)$-Hafnon $\left(\mathrm{HfSiO}_{4}\right)$ series, where zircon has $\# \mathrm{Hf}=0-10$; hafnian zircon, $\# \mathrm{Hf}=10-50$; zirconian hafnon, $\#$ Hf $=50-90$; and Hafnon, \#Hf $=90-100$. The term \#Hf denotes the hafnon end-member $\left(\mathrm{HfSiO}_{4}\right)$ mole $\%$ or more precisely, the atomic ratio: $100 * \mathrm{Hf} /(\mathrm{Zr}+\mathrm{Hf})$

Generally, the Hf content of most natural zircon crystals is $1-3$ wt \% $\mathrm{HfO}_{2}$ (Speer, 1982 and Cesborn et al., 1995). The most Hf-enriched zircon occur in evolved rock-types, it appears that the Hf abundance of zircon increases with magmatic differentiation (Hoskin and Schaltegger, 2003 \& Soba et al, 2007). Kempe et al. (1997) and Abadalla et al. (2008) considered that both magmatic and metasomatic mechanisms or a combination of them were responsible for yielding extreme $\mathrm{Zr} / \mathrm{Hf}$ fractionation and hence the formation of Hfrich zircon. The mentioned petrographical and geochemical characterization of both the metasomatically and magmatically specialized rare metal granitoids, however, has greatly assisted in clear discrimination of $\mathrm{Zr} / \mathrm{Hf}$ fractionation in the two main associations (i.e. magmatic and metasomatic).

In addition, the studied zircon exhibits $\mathrm{Ce}$ content $(0.014-0.080 \%)$, which is more than 
the most analyzed igneous zircon, which reported Ce abundances less than 50 ppm. Hoskin and Schaltegger (2003) and El Balakssy (2010) reported that the magamtic zircons contain less than $1 \mathrm{wt} \%$ total REE+Y. Occasionally, Ce which is light rare earth element (LREE) occurs in zircon structure due to the similarity of $\mathrm{Ce}$ and $\mathrm{Lu}$ in ionic radii (Hoskin and Schaltegger, 2003). $\mathrm{ZrO}_{2}$ and $\mathrm{HfO}_{2}$ (core and rim) from Nuqara rhyolite zircon were plotted on binary diagram (Fig.13) as modified from Kempe et al. (1997) and Abadalla et al. (2008) revealed that the study zircon lies in non defined trend (magmatic and metasomatic), therefore $\mathrm{Zr}$-Hf(U+ Th $+\mathrm{Y}+$ HREE) ternary diagram (Fig.14) of zircon from Nuqara rhyolite rocks was plotted to establish zircon origin. The dashed line represents an interpretative boundary that limits the compositional gap between the two zircon series. The shown trends of magmatic zircon (MZ) and metasomatic hydrothermal zircon (MHZ) are drawing by Abadalla et al. (2008) revealed that the studied zircon is related to magmatic zircon (MZ).

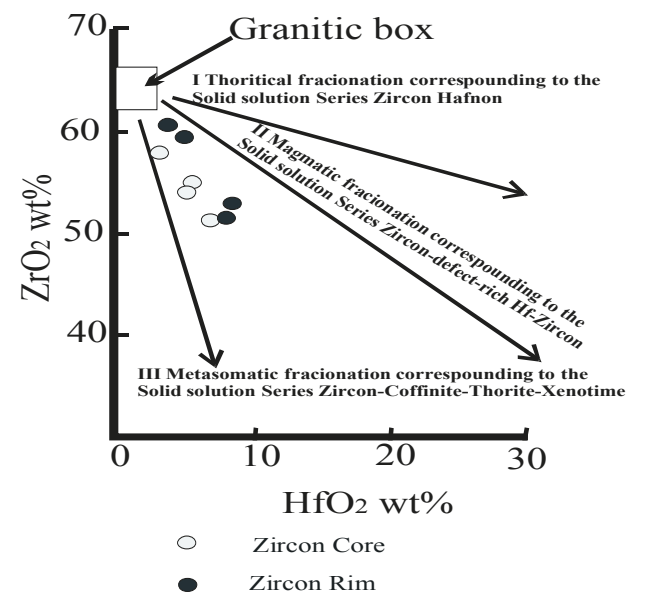

Fig. 13: $\mathrm{ZrO}_{2}$ versus $\mathrm{HfO}_{2}$ diagram of zircons from Nuqara rhyolite rocks. Kempe et al. (1997) and Abadalla et al. (2008)

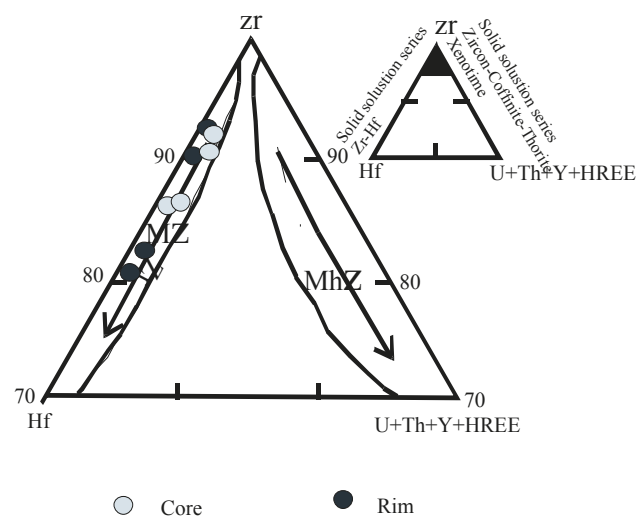

Fig. $14 \mathrm{Zr}-\mathrm{Hf}-(\mathrm{U}+\mathrm{Th}+\mathrm{Y}+$ HREE) ternary diagram of zircon from Nuqara rhyolite rocks by Abadalla et al. (2008)

\section{CONCLUSION}

The Dokhan volcanic of Gabal Nuqara, Central Eastern Desert are related to fissuretype eruption and are subdivided into intermediate and acidic volcanics. The acidic Dokhan volcanics are located as two elongated flows, trending NW-SE direction and cutting by younger granites and younger gabbros.

Petrographically, the acidic volcanic rocks are mainly rhyolite, dacite and their tuffs. Rhyolite is composed mainly of quartz, potash feldspars and plagioclase with uniform grain size. Allanite, zircon and opaque are the accessory minerals. Dacite is composed mainly of groundmass of quartz, plagioclase and potash feldspar and phenocrysts of perthite and plagioclase.

Radiomatically, tuffs and dacite rocks show low radioactivity, while the concerned rhyolite exhibits relatively high $\mathrm{eTh}$ and $\mathrm{eU}$ contents (140 ppm and $89 \mathrm{ppm}$ in average respectively). Moreover, an anomalous was recorded in rhyolite rocks where eTh and $\mathrm{eU}$ 
contents are $745 \mathrm{ppm}$ and $280 \mathrm{ppm}$ in average respectively. The studied rhyolites are more radioactive than the highly radioactive topaz rhyolites of the Toans range, northeastern Nevada which record average values of $\mathrm{eU}$ and eTh concentration 46 and 87 ppm respectively (Price et al., 1992).

Detailed mineralogical studies using ESEM and XRD techniques indicate that the presence of some minerals that responsible for the radioactivity of the Nuqara rhyolites such as thorite and uranothorite as primary radioactive minerals. Furthermore, samarskite, zircon and allanite occur as $\mathrm{U}$ +and Th-bearing accessory minerals. The mineral chemistry by EPMA analysis of thorite reflects the main components are $\mathrm{ThO}_{2}(38 \%), \mathrm{SiO}_{2}(33 \%)$ and $\mathrm{UO}_{2}(6 \%)$ while the main components of uranothorite are $\mathrm{ThO}_{2}(40 \%), \mathrm{SiO}_{2}(20 \%)$, and $\mathrm{UO}_{2}(12 \%)$. Beside, the studied zircon crystals display a large chemical variability between core and rim. This agree with Wayne et al. (1992) in addition to Hanchar and Miller (1993) who documented very large differences in $\mathrm{U}, \mathrm{Hf}$ and $\mathrm{Y}$ concentrations between core and rim in a single zircon crystal. They interpreted this effect as a redistribution of these elements along grain boundaries due to recrystallization during high-grade metamorphism. The presence of pyrite is good indicator for the reducing environment favorable for the occurrence of radioactive mineralization

The genesis of zircon exhibits to magmatic zircon (MZ). Zircon and thorite are demonstrably magmatic origin, can be attributed concentrated in the rhyolite extrusive rocks in the late stage of the end volcanoes in the study area. From the study rhyolite in the studied area, contains the high concentrations $\mathrm{Th}, \mathrm{Zr}$, $\mathrm{U}$, and REE. Accordingly, the study rhyolite represents a favorable source for rare metals of Th, Zr, U, and REE.

\section{REFERENCES}

Abadalla H.M., Helba H. and Matsueda H., 2008. Chemistry of zircon in rare metal granitoids and associated rocks, Eastern Desert, Egypt. Resource Geology, 59, 51-68.

Abdel Warith, A., Raslan, M.F. and Ali, M.A.,2007. Mineralogy and radioactivity of pegmatite bodies, from the granitic plutun of Gabal Um Tajer El Tahtani area, Central Eastern Desert, Egypt. 10th Inter. Mining Petrol. and Metall. Eng., Conf. No.30.

Ali, M.A., 1995. Geology and distribution of radioactivity in some rock units around Gabal Nuqara. M.Sc. Thesis, Cairo Univ., 187 p.

Bao, X., 1995. Two trends of composition variation of zircons and their significance in origin discrimination, Acta Mineralogica Sinica, 15(4), 404-410.

Basta, E.Z., Kamel, O.A. and Awadallah, M.F.,1978. Petrography of gebel Dokhan volcanics, Eastern Desert, Egypt. J. Geol., 22, No.2, 145-171.

Basta, E.Z., Kotb, I.I. and Awadallah, M.F.,1980. Petrochemical and geochemical characteristics of the Dokhan formation at the type locatity, Gebel Dokhan, Eastern Desert, Egypt. In: AlShanti A.M.S. (Ed.), Evolution and mineralization of The Arabian Nubian Shield. Pergamon Prees, New York, 3, 122-140.

Bibikova, E.B., 1979. Zircon-an isotope geological clock. Translated by Hu Heqin. Geology Geochemistry, 10, 69 .

Cesborn, F., Blanc, P., Ohnenstetter, D. and Remond, G., 1995. Cathodo-luminescence of rare earth doped zircons. Their possible use as reference materials: Scanning Microscopy, Suplements. 9, 35-56.

Dawood, Y.H., Abd El-Naby, H.H. and Sharafeldin, A.A., 2004. Influence of the alteration processes on the origin of uranium and europium anomalies in trachyte, Central Eastern Desert, Egypt. J. Geochem. Exp., 88, 15-27. 
El Balakssy, S.S., 2010. Zircon zonation from Egyptian coastal sediments as genetical indicator. J. Mineral. Soc. Egypt, Nat. Res. Center. Cairo, Egypt. In press.

El-Mansi, M.M., Dadrier, A.M. and Abdel Warith, A., 2003. Geology and uranium distribution in Gabal Nuqara Dokhan volcanics, Central Eastern Desert, Egypt. Egypt. J.Geol., 47(2), 619632.

Engel, A.E.J., Dixon, T.H. and Stern, R.J., 1980. Late Precambrian evolution of Afro-Arabian crust from Ocean arc to Craton. Geol. Soc. Am. Bull., Part I, 91, 699-706.

Förster, H.J.,2006. Composition and origin of intermediate solid solutions in the system thoritexenotime-zircon-coffinite. Lithos, 88, 35-55.

Frondel, J.W. and Cuttito, A.,1955. Glossary of uranium and thorium-bearing minerals. Geol. Surv.Am, 5,1009 p.

Hammad, H.M.,1978. Petrology of the volcanic rocks on Gebel Nuqara area, West Safaga, Eastern Desert, Egypt. M. Sc. Ain Shams Univ., Cairo, $130 \mathrm{p}$.

Hanchar, J.M. and Miller, C.F.,1993. Zircon zonation patterns as revealed by cathodoluminescence and backscattered electron images; implications for interpretation of complex crustal histories. Chem. Geol., 110, 1-13.

Hassan, A. M. and Long, L.E.,2007. Rb-Sr chronology of Dokhan volcanics, Eastern Desert, Egypt. 2nd Inter. Conf. Geol. Tethys, Cairo University. Egypt.

Heikal, M.A., Higazy, M.H. and El-Rahmany, M.M.,1980. Ignimbritic rhyolites in the Wasif area, Eastern Desert, Egypt. Bull. Inst. Applied Geol., King Abdul Aziz Univ., Jeddah, 4(3), 107-114.

Hilmy, M.E., Meneisy, M.Y., Ragab, A.I. and Hammad, H.M.,1983. Petrology of the volcanic rocks of Gabal Nuqara west of Safaga. Ain Shams Sci. Bull., 22(B), 1-24.
Hoskin, P.W.O. and Schaltegger, U., 2003. The composition of zircon and igneous and metamorphic petrogenesis. In Hanchar, J and Hoskin, P. W. O. (Eds.), zircon. Mineralogical Society of America and Geochemical Society Reviews in Mineralogy and Geochemistry, 53, 27-62.

Hume, W.F., 1934. Geology of Egypt. VII (I), the metamorphic rocks. Surv. Egypt, Cairo.

Ibrahim, M.E., Attawiya, M.Y., Osman, A.M. and Ibrahim, I.H., 2002.Occurrence of uranium bearing minerals in Um Safi pyroclastics, Central Eastern Desert, Egypt. Egypt. J. Geol., 46(1), 39-54.

Kempe, U., Gruner, T., Renno, A.D. and Wolf, D.,1997. Hf- rich zircons in rare-metal bearing granites: Magmatic or metasomatic origin. In Papunen, H.(Ed.), Mineral deposits. Research and exploration where do they meet? Balkema, Rotterdam, 643-646.

Klepper, M.R., and Wyant, D.G., 1956. Uranium provenance. In: Stocking, H.E. and Smith, H.B. (Eds.), Contributions to the geology of uranium and thorium by the United Stated Geological survey and atomic energy commission for the United nations international conference on peaceful uses of atomic energy, Geneva, Switzerland,1955,U.S.Geol. Surv. Professional Paper,300,17-26.

Pagel, M.,1982. The mineralogy and geochemistry of uranium, thorium, and rare-earth elements in two radioactive.

Price, J.G., Castor, S.B. and Miller, D.M.,1992. Highly radioactive topaz rhyolites of the Toano Range, northeastern Nevada. Am. Mineral., 77, 1067-1073.

Rankama, K. and Sahama, T.G., 1955. Geochemistry. Chicago Univ. Press. Chicago. 37p.

Ragab, A.I., 1987. The Pan-African basement of the Northern segment of the Eastern Desert of Egypt; A crustal evolustion model and its implications on tectonostrtigraphy and granite types. M.E.R.C. Ain Shams Univ., Earth Sci., 1,1-18. 
Reis, A. C., Shackleton, R. M., Graham, R.H. and Fitches, W.R.,1983.Pan-African structures, ophiolites and melange in the Eastern Desert of Egypt; A traverse J. Geol. Soc. London, 140, 75-95.

Soba, C.P., Villaseca, C., Del Tanago, J.G. and Nasdala, L., 2007. The composition of zircon in the peraluminous Hercynian granites of the Spanish central system batholith. Canad. Mineral., 45(3), 509-527.

Speer, J. A.,1982. Zircon. In: Ribbe, P. H. (Ed.), Orthosilicates, 2nd edition, Reviews in Mineralogy, 5, 67-112.
Wark, D.A. and Miller, C.F., 1993. Accessory mineral behaviour during differentiation of a granite suite: monazite, xenotime and zircon in the Sweetwater Wash pluton, Southeastern California, U. S. A. Chem. Geol.,110, 49-67.

Wayne, D.M., Sinha, A.K. and Hewitt, D.A.,1992. Differential response of zircon U-Pb isotopic systematics to metamorphism across a lithological boundary: an example from the Hope Valley shear zone, southeastern Massachusetts, U.S.A. Contr. Min. and Petro., 109, 408-420. 


\section{معدنية وإثعاعية بركانيات الاخان الحامضية ـ جبل نقارة وسط الصحراء الثرقية, مصر \\ صلاح صبحى البلاقصى و محمد احمد على و محمد عمر الحسينى}

بركانيات الدخان الحامضية لجبل نقارة وسط الصحر اء الثرقية يكون من النو ع الحامضى تملئ شروخ خالبركانيات فى الكي

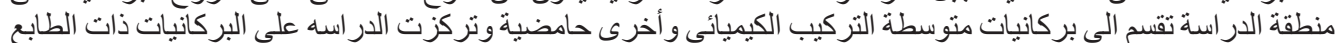

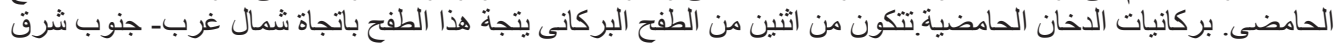

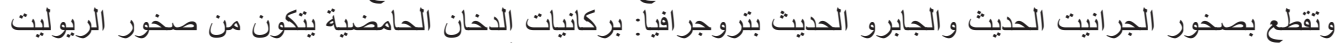

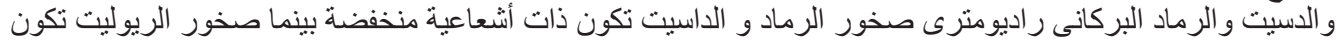

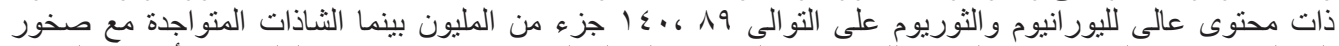

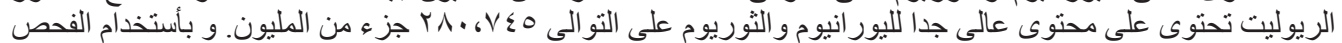

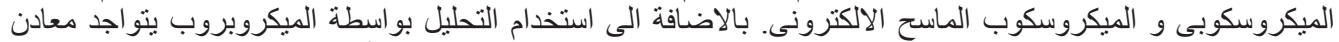

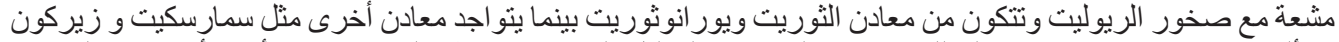

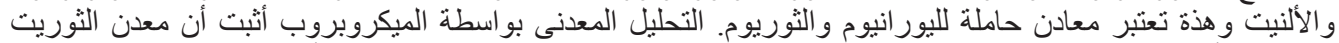

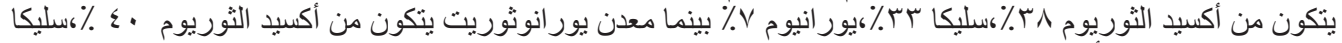

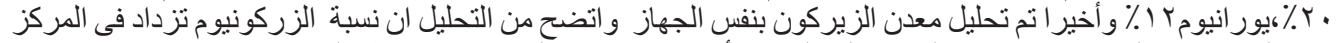

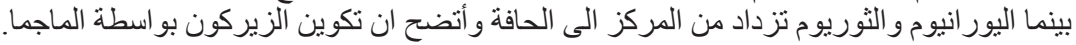

